\title{
A MODEL INVESTIGATION OF INTERANNUAL SEA-ICE VARIABILITY IN THE BEAUFORT SEA
}

\author{
By BECKY Ross \\ (Department of Atmospheric Sciences, University of Illinois, Urbana, Illinois 61801, U.S.A.)
}

\begin{abstract}
Model-generated ice-thickness fields for the period 1961-80 are examined in the context of summertime sea-ice predictability in the Beaufort Sea. The correspondence between the modeled and observed fluctuations of ice-covered area is found to be quite good. Lag correlation coefficients based on departures from 20 year "normals" of the ice thicknesses show that the ice anomalies are persistent throughout the August-May period. However, because the thickness anomalies undergo large fluctuations during July and August, only a small amount of summertime predictability can be derived from the thickness data. The findings are consistent with the observational results of Rogers (1978), who found that summertime temperatures and wind directions accounted for much of the variability of Beaufort Sea ice during August and September.
\end{abstract}

RÉsumé. Un modèle d'examen de la variabilité interannuelle de la glace de mer dans la mer de Beaufort. Des épaisseurs de glace issues d'un modèle établi pour la période 1961-80 sont examinées dans le cadre de la prédiction de la glace de mer estivale pour la mer de Beaufort. La concordance entre les fluctuations de l'extension de la glace modélisées et observées est réellement bonne. Des corrélations des coefficients de retard basées sur les écarts par rapport à une "normale" sur 20 ans des épaisseurs de glace montrent que des anomalies de glace sont vraiment persistantes pour la période précédant août à mai. Cependant parce que les anomalies d'épaisseur subissent de grandes fluctuations pendant juillet et août, seulement une petite partie de

\section{INTRODUCTION}

Previous studies of the interannual variability in Beaufort Sea summer ice conditions have primarily used observational data. In one such study, Rogers (1978) compared air temperature, sea-level pressure, and wind data with observed summertime ice extent. A high correlation $(r=0.815)$ was found between the number of warm-season thawing degree-days and the distance of the ice edge to Pt Barrow on 15 September. The number of summer days with northerly (or southerly) surface winds was also significantly correlated with the distance from the ice edge to the coast. Moreover, the correlation between late-summer ice extent and all meteorological variables increased through the summer, suggesting that the most important meteorological parameters were the most recent ones. Rogers approached the problem of longer-range prediction of summer ice conditions by attempting to correlate the number of cold-season freezing degreedays with the subsequent number of warm-season thawing degree-days. Although not statistically significant, the negative correlation did imply the existence of a weak relationship.

Rogers' results left open the possibility that other (non-meteorological) variables might add to the long-range predictability of summertime ice conditions. Large-scale sea-ice model simulations provide an opportunity to supplement observational data with variables such as ice thickness and velocity which are not routinely observed. Ice thicknesses generated in a 20 year model simulation of sea-ice fluctuations in the northern hemisphere are used in this paper to examine ice variability in the Beaufort Sea. Of particular interest is any evidence indicating that the predictability of summer sea-ice conditions can be enhanced by model-derived ice-thickness data for preceding months and seasons. la prédiction estivale peut être établie à partir des données d'épaisseur. Les résultats sont cohérents avec ceux observés par Rogers (1978), qui trouve que les températures et les directions de vent estivales rendent compte de la majeure partie de la variabilité de la mer de Beaufort pour août et septembre.

Zusammenfassung. Eine Modellstudie der Veränderlichkeit von Meereis während des fahres in der Beaufort-See. Im Zusammenhang mit der Vorhersagbarkeit der sommerlichen Meereisbedeckung in der Beaufort-See wurden simulierte Eisdickenfelder für die Periode 1961 bis 1980 untersucht. Die Übereinstimmung zwischen den modellierten und den beobachteten Schwankungen der Eisbedecküng erweist sich als recht gut. Autokorrelationsrechnungen auf der Basis von Abweichungen gegenüber 20-jährigen "Norm"-Dicken des Eises zeigen, dass die Eisanomalien für die vorausgehende Periode August bis Mai sehr beharrlich sind. Da jedoch die Dickeanomalien im Juli und August starken Schwankungen unterworfen sind, kann aus den Dickedaten nur eine geringe Vorhersagbarkeit für die Sommerzeit hergeleitet werden. Dieser Befund stimmt mit den Beobachtungsergebnissen von Rogers (1978) überein, der feststellte, dass vor allem Temperaturen und Windrichtungen im Sommer für die Veränderlichkeit des Meereises in der Beaufort-See während der Monate August und September verantwortlich sind.

\section{MODEL SUMMARY}

The thickness fields were generated from the dynamic/thermodynamic model developed by Hibler (1979, 1980). The essential features of the model are (a) a momentum balance based on geostrophically derived air and water stresses, Coriolis force, ocean tilt, internal ice stress, and inertial terms; (b) an ice rheology based on a viscous-plastic constitutive law and an ice strength parameter $P^{\star}$; (c) an ice-thickness distribution characterized by the compactness $A$ and the mean ice thickness $h$ averaged over an entire grid cell; (d) a thermodynamic code in which vertical growth rates are estimated form heat-budget computations at the top and bottom surfaces of the ice and from the heat stored in a motionless oceanic boundary layer.

The thermodynamic code has been modified to include an explicit treatment of snow cover and multilevel thermodynamic computations (Walsh and others, in press). In previous simulations snow cover was parameterized only through the surface albedo, which was assigned a value corresponding to ice or snow when the air temperature was above or below freezing, respectively. Snow is now accumulated during the nonsummer months according to the prescribed accumulation rates of Parkinson and Washington (1979). When the ain temperature is above freezing, the snow must melt completely before the ice thickness is reduced by surface melt. The surface albedos of snow and ice are 0.80 and 0.65 , respectively.

Thermodynamic computations were previously performed for two levels: open water $(h=0)$ and an effective thickness $h$ eff representing the mean thickness of ice in the ice-covered portion of the grid cell. In order to incorporate the strong thickness dependence of ice growth rates (e.g. Maykut, 1982), heff is replaced by a seven-level distribution of thickness 
equally spaced between 0 and $2 h$ eff. Under growth conditions the snow cover is similarly partitioned into a seven-level linear distribution of snow depths. This strategy is based on the assumption that thin (new) ice will generally be covered by less snow than will thick (old) ice. Under melt conditions, which generally occur in spring and summer after much of the snow has been subjected to considerable blowing and drifting, the snow is assumed to be uniformly distributed over the ice-covered portion of each grid cell. The snow distribution corresponding to melt conditions is imposed whenever the surface temperature exceeds $0^{\circ} \mathrm{C}$ at the surface of ice of thickness $h_{\text {eff }}$.

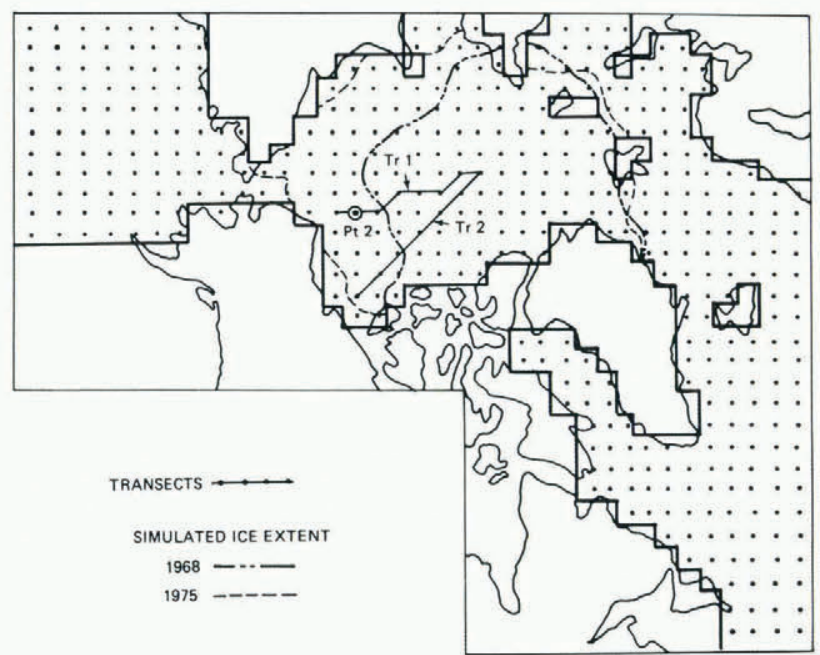

Fig. 1. The model grid and two transects in Beaufort Sea. Also 31 August simulated ice extent for 1968 and 1975 .

The domain used is a $38 \times 31$ grid with a resolution of $222 \mathrm{~km}$ (Fig. 1). The model is run with a oneday time-step using atmospheric forcing data from the period 1961-80. Daily wind fields are computed geostrophically from the NCAR (National Center for Atmospheric Research) set of Northern Hemisphere sea-level pressure analyses, which are in the form of $5^{\circ} \times 5^{\circ}$ latitude-longitude grids. Air temperature anomalies are obtained from the so-called "Russian surfacetemperature data set" (Vinnikov, 1977; Robock, 1982), which contains monthly temperature anomalies for the Northern Hemisphere on a $5^{\circ} \times 10^{\circ}$ latitude-longitude grid. These anomalies are added to the climatological monthly mean temperatures of Crutcher and Meserve (1970) and interpolated bilinearly to the ice-model grid. Daily temperatures are then computed by a cubic spline interpolation from the monthly values, which are assumed to correspond to the mid-points of the respective calendar months. Because the Russian temperature data set available for this work ended with December 1976, monthly climatological mean temperatures were used for the final four years (1977-80). The monthly means were computed from the temperatures of the first 16 years (1961-76) of the simulation period.

Thicknesses (mean ice thickness $h$, rather than $h_{\text {eff }}$ used in the post-processing are those from the last day of each month. Results are derived using all twenty years of model data (1961-80). In order to investigate Beaufort Sea ice, two transects containing seven points each were chosen from the model grid (Fig. 1).

An important consideration when using model results is the degree of correspondence with actual observation. The model-generated August ice extent for two extreme years, 1968 and 1975 (Fig. 1), agrees well with the observed light ice conditions in 1968 and
TABLE I. BEAUFORT SEA ICE-SEVERITY RANKING OF SUMMERS 1961-80 WITH DISTANCE FROM PT BARROW TO ICE EDGE AND TO 0.5 ICE CONCENTRATION ON 15 SEPTEMBER (U.S. NAVAL POLAR OCEANOGRAPHIC CENTER, 1983)

$\begin{array}{rrrr}\text { Rank } & \text { Year } & \begin{array}{c}15 \text { September } \\ \text { distance to } \\ \text { ice edge } \\ \mathrm{km}\end{array} & \begin{array}{c}15 \text { September } \\ \text { distance to } 0.5 \\ \text { ice concentration } \\ \mathrm{km}\end{array} \\ 1 & 1968 & 305.2 & 370.0 \\ 2 & 1973 & 148.0 & 351.5 \\ 3 & 1962 & 277.5 & 277.5 \\ 4 & 1963 & 240.5 & 240.5 \\ 5 & 1961 & 194.2 & 249.8 \\ 6 & 1979 & 231.3 & 231.3 \\ 7 & 1974 & 185.2 & 185.2 \\ 8 & 1978 & 129.5 & 175.7 \\ 9 & 1977 & 101.7 & 157.3 \\ 10 & 1972 & 111.0 & 166.5 \\ 11 & 1967 & 0.0 & 92.5 \\ 12 & 1966 & 0.0 & 83.2 \\ 13 & 1965 & 18.5 & 129.5 \\ 14 & 1980 & 46.3 & 46.3 \\ 15 & 1976 & 27.8 & 27.8 \\ 16 & 1971 & 0.0 & 55.5 \\ 17 & 1964 & 0.0 & 9.2 \\ 18 & 1970 & 0.0 & 0.0 \\ 19 & 1969 & 0.0 & 55.5 \\ 20 & 1975 & 0.0 & 0.0\end{array}$

heavy ice conditions of 1975 (Table I). As a further check, lag correlations of July model ice concentration anomalies with those of following months are shown in Figure 2. Also shown are the lag correlations of observed July ice concentration anomalies with those of following months in the long. $150-155^{\circ} \mathrm{W}$. sector for the 25 year period 1953-77 based on the data of Walsh and Johnson (1979). These correlations are undefined for the winter months December-March due to the absence of variability in ice-covered area, i.e. the region is completely ice-covered during winter. The lag correlations of both model and observed data decay similarly indicating that model processes are occurring on a similar time scale to observed events.

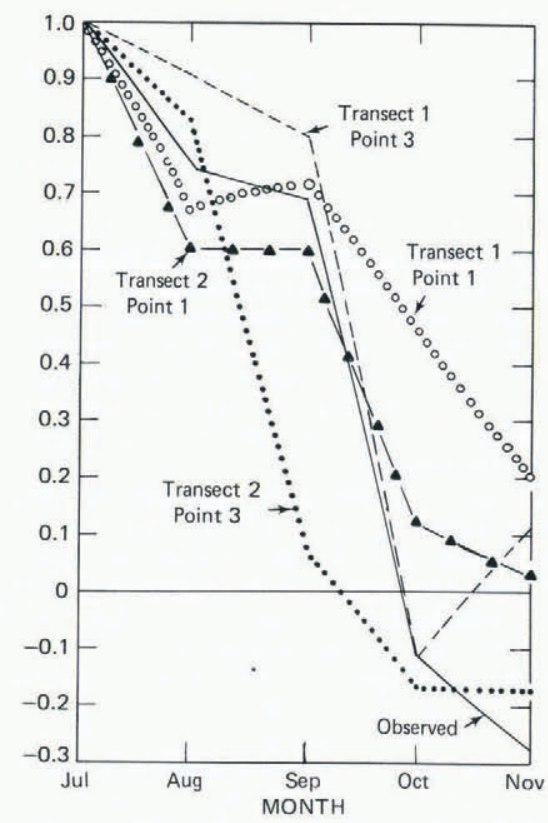

Fig. 2. Lag correlations of July ice concentration anomalies and those of following months for 1) $o b$ served data from long. $150^{\circ}-155^{\circ} \mathrm{W}$ sector over the period 1953-7? (solid line) and 2) model data for 1961-80 (points 1 and 3 from each transect). 
It is not possible to check the correspondence of model and observed ice thicknesses as closely due to the lack of observed thickness data. However, Figure $3 a$ compares model ice thickness at point 2 , transect 1 (near the ice edge) on 31 August with the observed distance north of Pt Barrow to the ice edge on 15 September. Similarly, Figure $3 b$ compares the observed
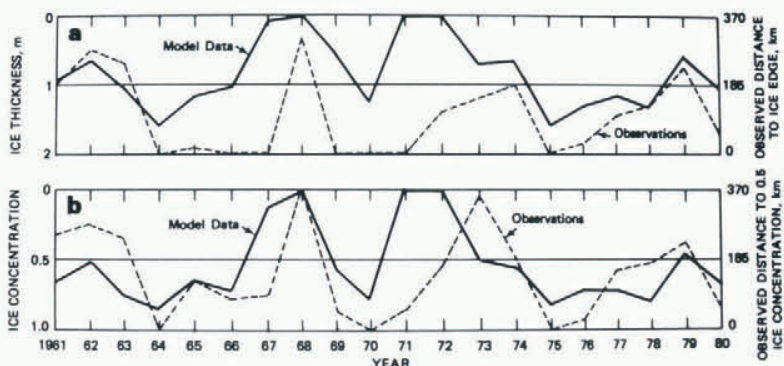

Fig. 3. Time series comparing model data with observations; (a) shows model ice thickness $h$ at point 2 , transect 1 on 31 August and observed distance from Pt Barrow to ice edge on 15 september, (b) compares model ice concentration at point 2 , transect 1 on 31 August and observed distance to 0.5 ice concentration on 15 September.

distance north to an ice concentration of 0.5 on 15 September with the model-generated ice concentration at point 2 on 31 August. The agreement is surprisingly good in view of the fact that there will not necessarily be a direct correspondence between anomalies of ice thickness and ice extent.

\section{RESULTS}

A scatter-plot (Fig. 4) of January thickness and the maximum spring thickness (April or May) shows a strong relationship between the two variables, indicating that the thickness anomalies show some continuity over several months in the early part of the year. Since this plot contains points from both transects throughout the 20 year period, it appears the relationship is valid in general for the Beaufort Sea area. Monthly lag correlations computed at each point along the transects increase from $0.78(0.62$, transect 2$)$ at the coast to 0.93 at the pole.

Lag correlations of August thickness anomalies with those of following months are shown in Figure 5 for both transects. The correlations for the coastal

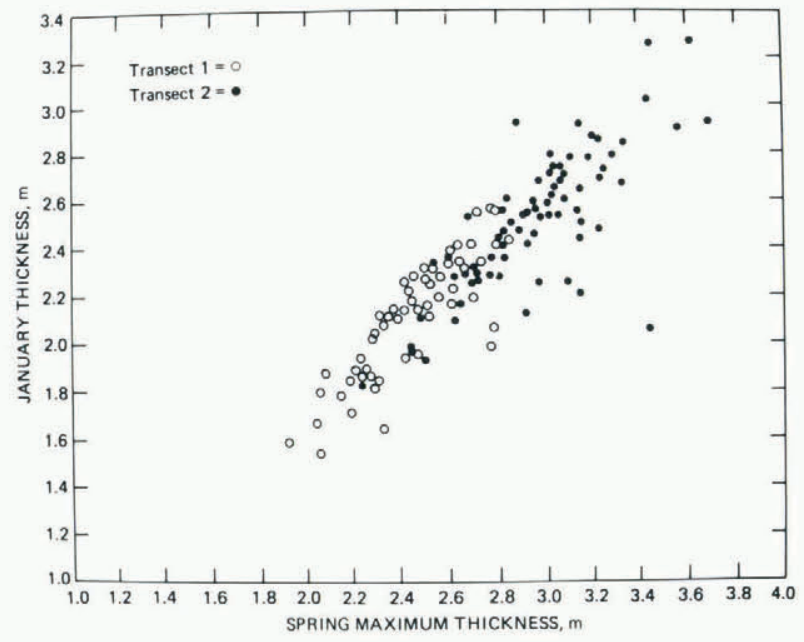

Fig. 4. Scatter-plot of 31 Janwary thickness and maximum spring thickness using points 2-5 from transects 1 and 2 .
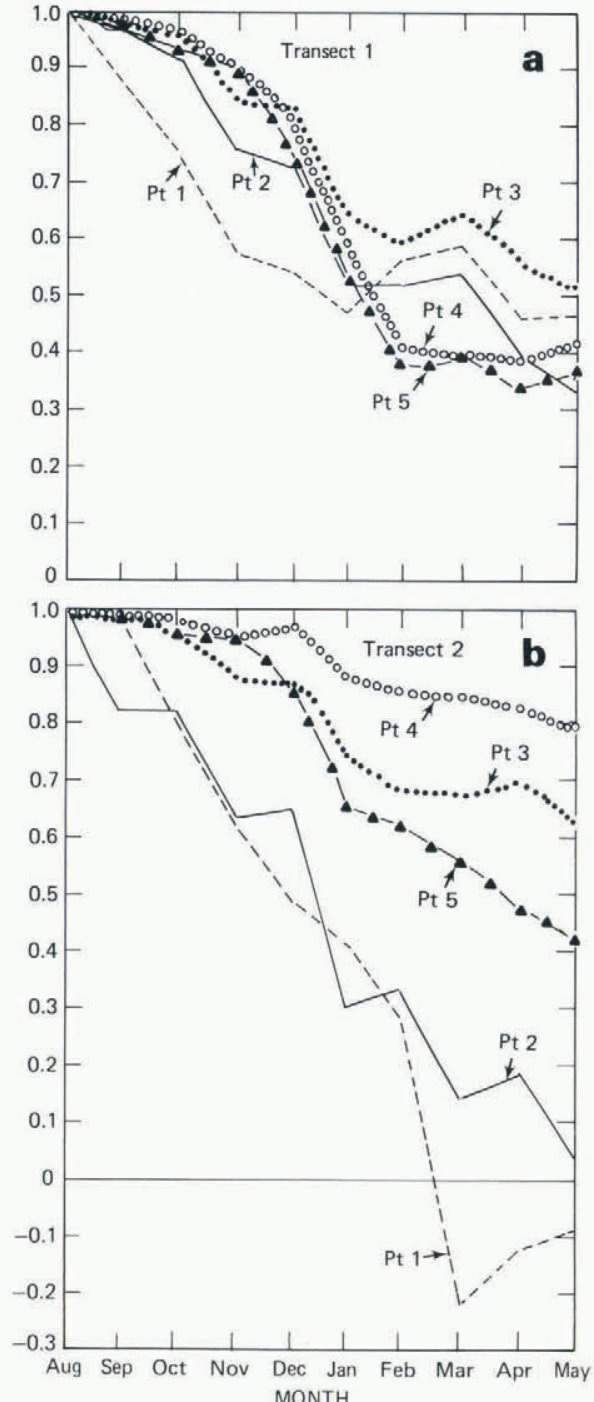

Fig. 5. Lag correlations of simulated August thickness anomalies and those of following months for (a) transect 1 and (b) transect 2 .

points fall off erratically with lag because the August thicknesses at these points are generally zero. Except for the coastal points, the correlations decay slowly even through the following May which supports the earlier finding (Fig. 4) that the thickness anomalies are persistent.

Time-series plots of June, July, and August thickness (point 2, transect 1) are shown in Figure 6. The July and August thicknesses show a substantial increase in variability compared with June. Although the June thicknesses are positively correlated with those of July and August, there is no reliable indication in the June data field of the occasionally large changes from year to year in July and August thicknesses.

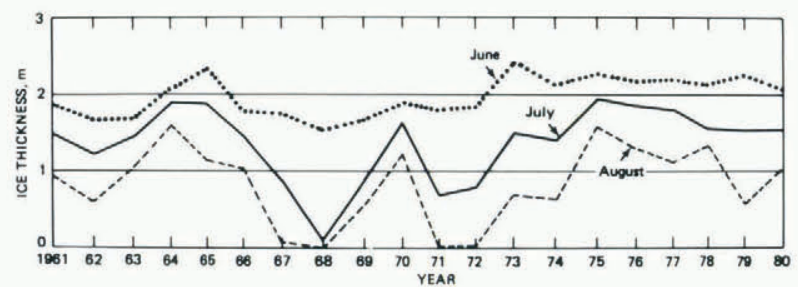

Fig. 6. Time series of simulated ice thickness for the months of Jwe, July, and August at point 2, transect 1. 


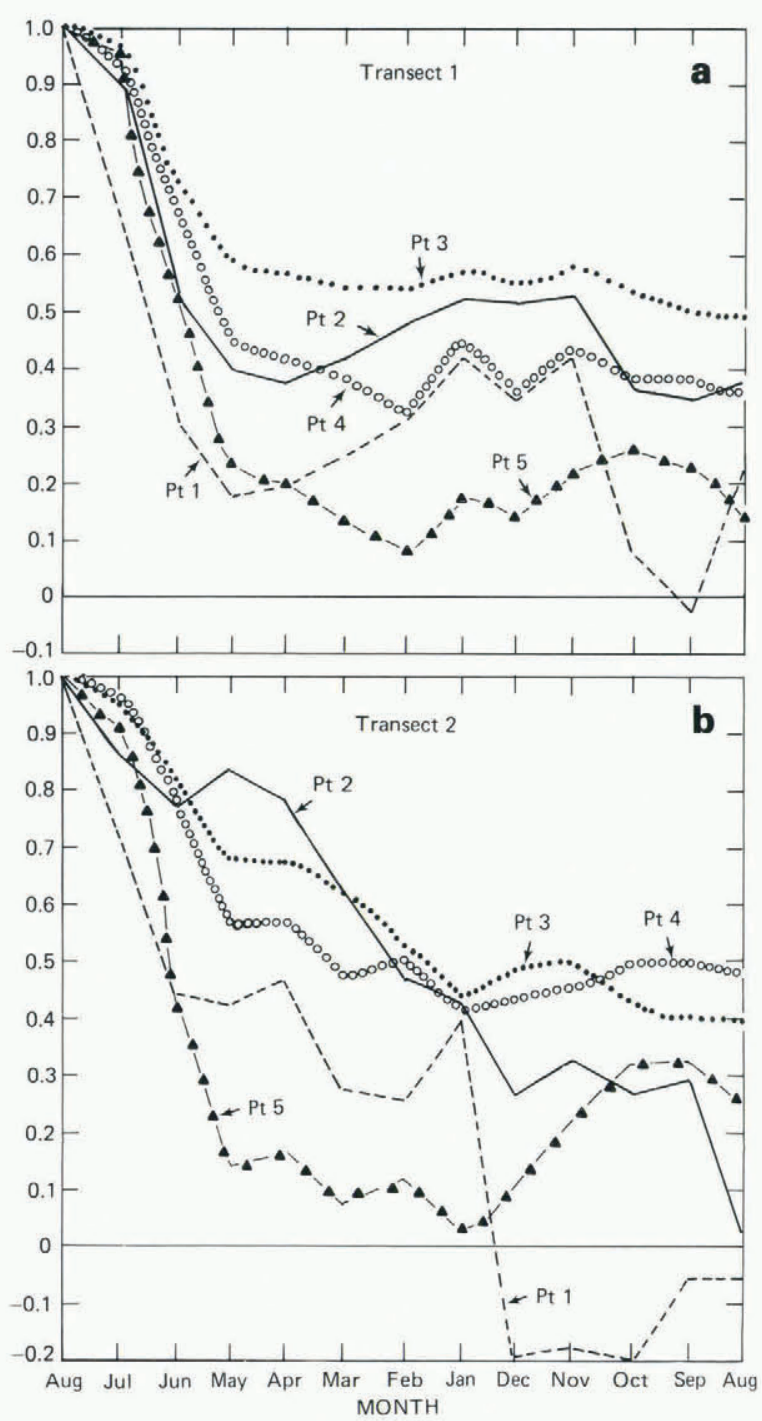

Fig. 7. Lag correlations of simulated August thickness anomalies and those of preceding months for (a) transect 1 and (b) transect 2 .

Figure 7 shows lag correlations of August thickness anomalies with those of preceding months for both transects. Since the $95 \%$ significance level of an independent sample of 20 is 0.45 , the correlations between the August anomalies and those of the preceding August-May (assuming them to be nearly independent) are marginally significant, suggesting that the summer ice minimum is somewhat influenced by the preceding winter and fall thicknesses. However the large differences in lag correlations with the May and July anomalies (together with Figure 6 ) suggest that events immediately preceding the late-summer ice minimum outweigh the cumulative effects of the thermal and dynamic history experienced by the ice during earlier seasons.

\section{CONCLUSIONS}

Twenty years of model-generated thickness fields (1961-80) have been examined for the Beaufort Sea to investigate the potential of ice thickness as a predictor of summer ice conditions. Thicknesses from late spring and summer months have been compared with those from preceding months by means of time series and scatter-plots as well as correlations of thickness anomalies.
A strong relationship exists between January thickness anomalies and the spring thickness maximum. Lag correlations between thickness anomalies of August and those of subsequent months show that ice anomalies are persistent on seasonal to yearly time scales. August thickness anomalies are also somewhat significantly correlated with those of the preceding winter at several of the grid points considered here. However, the large changes in July and August ice thicknesses from year to year are often unpredictable solely on the basis of thickness data from previous months. This finding is reinforced by the tendency for August thicknesses to correlate much more strongly with July thickness anomalies than with May thickness anomalies. The results support the conclusion of Rogers that atmospheric fluctuations become progressively more important throughout the summer in affecting ice conditions in the Beaufort Sea. While there seems to be some potential for the use of thickness fields as predictors, the optimal approach to summer ice predictability is likely to be based on short-term atmospheric forecasts in addition to modelderived sea-ice data.

\section{ACKNOWLEDGEMENTS}

This material is based upon work supported by the National Science Foundation, Division of Polar Programs, under Grant DPP81-20136. The author wishes to thank John Walsh for his valuable comments and John Brother for the drafting.

\section{REFERENCES}

Crutcher, H.L., and Meserve, J.M. 1970. Selected level heights, temperatures, and dew points for the northern hemisphere. Washington, D.C., U.S. Naval Weather Service Command. (NAVAIR Report 50-1C-52, revised.)

Hibler, W.D., III. 1979. A dynamic thermodynamic sea ice model. Jownal of Physical Oceanography, Vol. 9, No. 4 , p. $815-46$.

Hibler, W.D.,III. 1980. Modeling a variable thickness sea ice cover. Monthly Weather Review, Vol. 108, No. 12 , p. 1943-73.

Maykut, G.A. 1982. Large-scale heat exchange and ice production in the central Arctic. Jownal of Geophysical Research, Vol. 87, No. C10, p. 7971-84.

Parkinson, C.L., and Washington, W.M. 1979. A largescale numerical model of sea ice. Joumal of Geophysical Research, Vol. 84, No. C1, p. 311-37.

Robock, A. 1982. The Russian surface temperature data set. Jownal of Applied Meteorology, Vol. 21, No. 12, p. 1781-85.

Rogers, J.C. 1978. Meteorological factors affecting interannual variability of summertime ice extent in the Beaufort Sea. Monthly Weather Review, Vol. 106, No. 6, p. 890-97.

U.S. Naval Polar Oceanography Center. 1983. U.S. NavyNOAA joint ice center seasonal outlook western Arctic ice 1983. Washington, D.C., U.S. Navy Dept.

Vinnikov, K. Ya. 1977. K voprosu o metodike polucheniya i interpretatsii dannykh ob izmenenii prizemnoy temperatury vozdukha severnogo polushariya za period 1881-1975 gg. [On the problem of the method for obtaining and interpreting data on change in surface air temperature in the northern hemisphere during the period 1881-1975]. Meteorologiya $i$ Gidrologiya, 1977, No. 9, p. 110-14.

Walsh, J.E., and Johnson, C.M. 1979. An analysis of Arctic sea ice fluctuations, 1953-77. Jownal of Physical oceanography, Vol. 9, No. 3, p. 580-91.

Walsh, J.E., and others. In press. A model simulation of 20 years of northern hemisphere sea ice fluctuations, by J.E. Walsh, W.D. Hibler III, and B. Ross, Annals of Glaciology, Vol. 5 . 